\title{
Penerapan Model Pembelajaran Kooperatif Tipe STAD (Student Teams Achievement Division) Untuk Meningkatkan Hasil Belajar Mata Pelajaran Desain Grafis Vektor
}

\author{
I Putu Suarbawa \\ SMK Negeri 1 Sukasada \\ e-mail: putusuarbawa23@gmail.com ${ }^{1}$
}

\begin{abstract}
Abstrak
Penelitian ini bertujuan meningkatkan hasil belajar mata pelajaran Desain gravis vektor pada siswa kelas X DKV SMK Negeri 1 Sukasada Semester Ganjil tahun pelajaran 2017/2018 dengan penerapan model pembelajaran Kooperatif tipe Student Team Achievement Division (STAD). Jenis penelitian ini adalah Penelitian Tindakan Kelas (PTK). Penelitian dilaksanakan sebanyak 2 siklus. Subyek penelitian adalah siswa kelas X DKV SMK Negeri 1 Sukasada tahun pelajaran 2017/2018 yang berjumlah 28 orang. Data dianalisis menggunakan kuantitaif dan kualitatif. Berdasarkan hasil penelitian didapatkan Terjadi peningkatan hasil belajar Desain gravis vektor siswa pada siklus I dengan rata-rata sebesar 78,7 yang termasuk ke dalam kategori kurang, dengan sedangkan ketuntasan klasikal sebesar $35,7 \%$. Sedangkan pada siklus II rata-rata Desain gravis vektor siswa sebesar 89,6 yang termasuk klasifikasi baik, dan ketuntasan klasikal sebesar $100 \%$ dari 28 siswa. Dari analisis data di atas model pembelajaran kooperatif tipe Student Team Achievement Division (STAD) terbukti efektif dalam meningkatkan hasil belajar Desain gravis vektor siswa.
\end{abstract}

Kata Kunci: Hasil belajar Desain gravis vektor, model pembelajaran kooperatif tipe STAD.

\begin{abstract}
This study aims to improve learning outcomes of vector design subjects in class $X$ DKV Vocational High School 1 Sukasada Odd Semester 2017/2018 school year by applying the Cooperative Division Student Achievement Division (STAD) learning model. This type of research is Class Action Research (CAR). The study was conducted in 2 cycles. The research subjects were class $X$ students of DKV SMK Negeri 1 Sukasada in the 2017/2018 school year which were accepted by 28 people. Data were analyzed using quantitative and qualitative. Based on the results of the research obtained an increase in learning outcomes vector gravis design students in the first cycle with an average of 78.7 which is included in the less category, with classical completeness of $35.7 \%$. While in the second cycle the average student vector gravis design was 89.6 which included good classification, and classical completeness of $100 \%$ of 28 students. From the data analysis above the cooperative learning model Student Team Achievement Division (STAD) proved effective in improving the learning outcomes of student vector gravis design.
\end{abstract}

Keywords: Learning outcomes Vector graphic design, STAD cooperative learning model 


\section{Pendahuluan}

Semua mata pelajaran telah menggunakan kurikulum KTSP baik dari model pembelajarannya sampai pada pengaplikasiannya, dimana Jurusan Multimedia mempunyai beberapa mata pelajaran yang harus ditempuh salah satunya adalah mata pelajaran Desain Grafis Vektor. Idealnya kegiatan pembelajaran dilaksanakan bukan hanya berpusat pada guru sebagai sumber pengetahuan (teacher center), tetapi melibatkan peran siswa secara aktif dalam proses pembelajarannya. Maka diperlukan sebuah media yang dapat mendukung aktivitas siswa dalam mempelajari mata pelajaran Desain Grafis Vektor sehingga siswa dapat belajar mandiri tanpa harus bergantung pada guru mata pelajaran dalam mengembangkan bakat dan potensi yang dimiliki. Agar materi ajar dapat dipahami dan pembelajaran terasa menarik, seorang guru harus tepat dalam memilih model pembelajaran yang sesuai dengan materi yang akan diajarkan. model pembelajaran yang digunakan guru juga merupakan hal yang sangat penting dalam menentukan keefektifan pembelajaran.

Berdasarkan hasil observasi awal yang telah dilakukan oleh peneliti, hasil belajar pada mata pelajaran Desain Grafis Vektor yang diperoleh pada saat observasi pada siswa kelas $X$ DKV SMK Negeri 1 Sukasada ditemukan beberapa masalah rendahnya hasil belajar pada mata pelajaran Desain Grafis Vektor tergolong kedalam kategori sangat kurang jika di bandingkan kedalam kretiria ketuntasan minimal (KKM) yakni 80\%. Berdasarkan hasil kuisioner, siswa kelas X DKV SMK Negeri 1 Sukasada menyatakan merasa kurang memahami materi yang disampaikan dan tidak adanya bahan belajar atau modul sebagai pegangan siswa untuk belajar. Selain itu juga siswa merasa bosan karena siswa pada umumnya hanya menerima informasi yang diberikan oleh guru. Siswa lebih cenedrung mendengarkan, menulis atau mencatat dan memprakekkan apa yang diperintahkan oleh guru. Guru lebih cenderung mengajar dengan metode ceramah ini menyebabkan siswa cepat merasa bosan, dan siswa menjadi kurang aktif. Keterbatasan koneksi internet di sekolah juga menjadi kendala siswa untuk mencari tahu materi-materi yang berhubungan dengan pelajaran, khususnya pada mata pelajaran Desain Grafis Vektor. Sehingga diperlukan adanya suatu solusi yang dapat mengatasi masalah tersebut.

Dalam proses pembelajaran masih berpusat pada guru (teacher centred) yang menjadi faktor rendahnya hasil belajar siswa. Semua hal tersebut berdampak pada siswa, yang ditandai dengan kurang adanya ketertarikan dari siswa dalam menerima pelajaran khususnya pada mata pelajaran Desain Grafis Vektor, siswa belum sepenuhnya bisa menerapkan materi sehingga hasil belajar siswa kurang maksimal.

Melihat kenyataan tersebut, maka peran guru sebagai pendidik perlu mendapatkan perhatian khusus di dalam penerapan model pembelajaran yang tepat, karena dengan penerapan model pembelajaran yang tepat akan dapat memacu semangat para siswa dalam mengikuti pembelajaran dan mendorong siswa mengembangkan pengetahuan yang dimiliki dengan pengetahuan yang didapatkan dari sekolah sehingga para siswa akan bersikap aktif dalam mengikuti pelajaran khususnya mata pelajaran Desain Grafis Vektor. Salah satu alternatif pemecahan masalah yaitu dengan menerapkan model pembelajaran kooperatif yang mampu meningkatkan hasil belajar siswa. Model pembelajaran tersebut adalah model pembelajaran kooperatif tipe STAD. Dengan menerapkan model pembelajaran seperti ini, sikap belajar siswa akan lebih baik, dan ini juga akan memperbaiki hasil belajar khususnya mata pelajaran Desain Grafis Vektor serta tujuan dari pembelajaran akan dapat tercapai sesuai dengan yang diinginkan.

Berdasarkan hasil observasi awal, maka peneliti menemukan alternatif pemecahan masalah untuk mengatasi situasi tersebut. Salah satu alternatif yang digunakan adalah dengan menerapkan model pembelajaran kooperatif tipe STAD. Pembelajaran ini tepat digunakan dalam mengatasi permasalahan di atas karena model pembelajaran ini menuntut siswa untuk mau mengajukan permasalahan yang dihadapi, bekerjasama, berdiskusi dan berinteraksi dengan anggota kelompoknya masing-masing. Disini siswa bukan hanya belajar dan menerima apa yang disajikan oleh guru, melainkan bisa belajar dari siswa lainnya serta mempunyai kesempatan untuk membelajarkan siswa yang lain. Selain itu, dengan adanya kuis pada setiap akhir pelajaran dan adanya penghargaan terhadap kelompok yang memperoleh skor tertinggi akan dapat memotivasi siswa untuk berusaha memahami materi dalam mengikuti pembelajaran di kelas. Karakteristik/ciri pembelajaran kooperatif tipe STAD adalah: (1) siswa belajar dalam kelompok/tim kecil beranggotakan 4-5 orang yang heterogen, (2) memperhatikan skor awal, yang bertujuan untuk mengetahui kemampuan awal siswa, (3) kuis, yaitu untuk mengetahui peningkatan kemampuan siswa secara individual tanpa bantuan dari orang lain, (4) skor 
kemajuan individu, yaitu untuk mengetahui tingkat kemajuan individu yang bertujuan untuk menentukan predikat masing-masing kelompok, (5) penghargaan kelompok, yaitu berupa sertifikat, atau papan pengumuman bagi kelompok yang meraih skor prestasi tertinggi.

Model STAD sangat menekankan pada kerjasama dalam kelompok belajar. Hal ini akan menuntut siswa untuk saling membantu, memberi motivasi, dan saling percaya satu sama lain. Pembelajaran yang menekankan pada kerjasama akan memberi kesempatan kepada siswa untuk belajar bekerjasama, berbagi pendapat, pengetahuan, pengalaman, mendengarkan pendapat orang lain, saling memotivasi dan aktif dalam kegiatan pembelajaran. Bentuk kerjasama dalam model STAD diwujudkan dalam pembentukan tim belajar siswa. Tim terdiri dari empat atau lima siswa yang mewakili seluruh bagian dari kelas dalam kinerja akademik, jenis kelamin, ras dan etnisitas. Fungsi dibentuknya kelompok adalah agar siswa anggota kelompok dapat bekerjasama menyelesaikan tugas yang diberikan dan saling membantu untuk menguasai materi dengan baik. Hal ini karena sesama siswa memiliki kesamaan bahasa, tingkat perkembangan intelektual dan pengalaman kedekatan sehingga membuat siswa lebih mudah memahami materi pelajaran.

Sintaks dalam model pembelajaran STAD menjadikan siswa sebagai pusat dalam kegiatan pembelajaran (Student Centered). Pembelajaran semacam ini akan meningkatkan intensitas keterlibatan siswa secara aktif di dalam proses pembelajaran. Proses aktif dalam bertanya dan berargumen ini memberikan kesempatan siswa untuk mengekspresikan dirinya dan menumbuhkan pemikiran kritis pada siswa. Siswa sebagai pusat dalam proses pembelajaran memungkinkan siswa untuk menghasilkan solusi yang baru atas suatu permasalahan yang diberikan oleh guru. Ekspresi diri, pemikiran kritis dan penemuan yang dilakukan oleh siswa tentunya akan menumbuhkan kreativitas dalam diri siswa. Hal ini akan berpengaruh positif terhadap suasana pembelajaran yang menyenangkan karena tidak ada pemberian penekanan pada siswa.

Hal tersebut didukung dengan beberapa penelitian yang menyebutkan bahwa model STAD memiliki pengaruh terhadap keaktifan dan hasil belajar siswa. Penelitian tentang model pembelajaran STAD dapat meningkatkan keaktifan belajar siswa antara lain dilakukan oleh Putro (2011) yang menyimpulkan bahwa penerapan pembelajaran kooperatif STAD terbukti dapat meningkatkan keaktifan belajar siswa. Hal ini dapat dilihat dari skor rata-rata keaktifan kelompok sebesar 62,5 pada siklus 1 dan 82,5 pada siklus 2, sehingga mengalami peningkatan sebesar $18,7 \%$. Sedangkan skor rata-rata keaktifan siswa (individu) mengalami peningkatan sebesar $15,4 \%$.

Penelitian tentang model pembelajaran STAD berpengaruh terrhadap hasil belajar siswa antara lain dilakukan oleh Utomo (2012) menyimpulkan bahwa terdapat pengaruh penerapan model pembelajaran STAD terhadap hasil belajar geografi di SMA Negeri 1 Purwosari. Dengan kata lain rata-rata skor hasil belajar siswa yang pembelajarannya menggunakan model STAD lebih tinggi dibandingkan dengan siswa yang menggunakan model konvensional. Kelas yang diberi perlakuan model STAD mempunyai rata-rata sebesar 54,02 , sedangkan kelas yang diberi perlakuan metode konvensional mempunyai rata-rata sebesar 32,15. Wati (2011) pada siswa kelas XI IPS di SMA Negeri 9 Malang memberikan kesimpulan bahwa pembelajaran metode kooperatif dengan menggunakan model STAD berpengaruh signifikan terhadap hasil belajar siswa pada materi jurnal umum. Rata-rata nilai untuk kelas kontrol sebesar 52,68 dan untuk kelas eksperimen sebesar 56,68. Rata-rata nilai siswa kelas eksperimen lebih tinggi dari kelas kontrol.

Berdasarkan dari hasil penelitian di atas, dapat diketahui bahwa pembelajaran dengan menggunakan model pembelajaran STAD lebih efektif dalam meningkatkan keaktifan dan hasil belajar siswa dalam proses pembelajaran. Oleh karena itu, peneliti akan menguji apakah hasil penelitian tersebut juga berlaku di SMAN 1 Kesamben dengan karakteristik materi dan karakteristik siswa yang berbeda dengan penelitian sebelumnya. Penelitian ini dilakukan pada materi atmosfer yang memiliki karakter materi berbeda dengan materi-materi pada penelitian sebelumnya. Penelitian ini akan dilakukan di SMA Negeri 1 Kesamben yang memiliki karater siswa yang berbeda dengan penelitian sebelumnya

Berdasarkan uraian di atas, maka peneliti akan mencoba melakukan penelitian dengan judul "Penerapan Model Pembelajaran Kooperatif Tipe STAD Untuk Meningkatkan Hasil Belajar Mata Pelajaran Desain Grafis Vektor Pada Siswa Kelas X DKV SMK Negeri 1 Sukasada Tahun Pelajaran 2017/2018. 


\section{Metode}

Penelitian ini termasuk ke dalam Penelitian Tindakan Kelas (PTK). PTK bertujuan untuk mewujudkan proses penelitian yang mempunyai manfaat ganda baik bagi peneliti yang dalam hak ini mereka memperoleh informasi yang berkaitan dengan permasalahan, maupun pihak subjek yang diteliti dalam mendapatkan manfaat langsung dari adanya tindakan nyata (Darmadi, 2011: 246).

Jenis penelitian yang digunakan oleh peneliti ialah menggunakan penelitian tindakan kelas (PTK) atau dikenal dengan istilah classroom action research. Dalam penelitian kolaboratif, pihak yang melakukan tindakan kelas adalah guru itu sendiri, sedangkan yang diminta melakukan pengamatan terhadap berlangsungnya proses tindakan adalah peneliti (Arikunto, 2012). PTK adalah proses pengkajian masalah pembelajaran di dalam kelas melalui refleksi diri dan upaya untuk memecahkannya dengan cara melakukan berbagai tindakan yang terencana dalam situasi nyata serta menganalisis setiap pengaruh dari tindakan tersebut (Sanjaya, 2014).

Dalam penelitian tindakan kelas ini dilaksanakan sebanyak dua siklus dengan masingmasing siklus terdiri dari dua kali pertemuan. Masing-masing siklus terdiri dari empat tahapan, yaitu: (1) Rencana tindakan, (2) Pelaksanaan tindakan, (3) observasi/evaluasi, dan (4) reflekasi. Pelaksanaan PTK dapat dilihat pada gambar 01. sebagai berikut. Agar lebih jelas, dapat di lihat pada gambar di bawah ini.

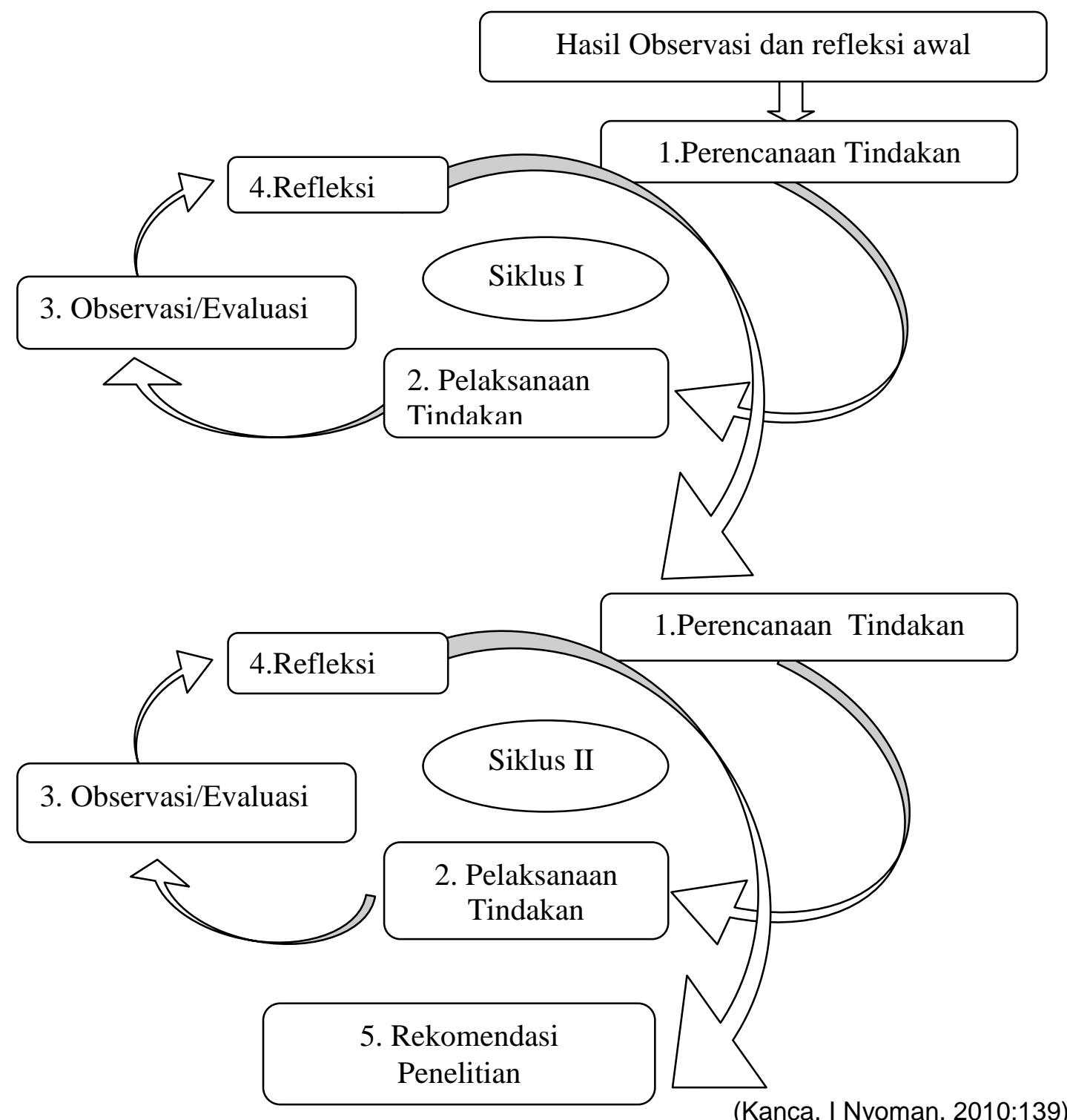

Gambar 1. Pelaksanaan Penelitian Tindakan Kelas 
Subyek dalam penelitian ini adalah siswa kelas X DKV SMK Negeri 1 Sukasada, dengan jumlah 28 orang siswa perempuannya 14 dan laki laki nya 14 orang. Dan yang menjadi Objek penelitian tindakan kelas ini adalah hasil belajar Desain gravis vektor siswa. Metode pengumpulan data yang digunakan dalam penelitian ini yaitu berupa Tes dan lembar pengamatan psikomotor sisiwa. Tes yang digunakan adalah tes uraian dan lembar pengamatan psikomotor siswa Adapun materi yang dijadikan poin di dalam PTK ini adalah Desain gravis vektor.

Data yang dikumpulkan dalam penelitian ini dianalisis dengan menggunakan analisis kuantitatif dan kualitatif. Data hasil belajar Desain gravis vektor siswa dianalisis secara deskriptif berdasarkan skor rata-rata $(\bar{X})$. Rumus yang digunakan untuk mengukur skor kemampuan matematika adalah:

$$
\bar{X}=\frac{\sum X}{N}
$$

(Arikunto, 2016)

Keterangan:

$$
\begin{array}{ll}
\bar{X} & =\text { rata-rata kelas } \\
\sum X & =\text { jumlah skor yang dicapai seluruh siswa } \\
\mathrm{N} & \begin{array}{l}
\text { = banyak siswa }
\end{array}
\end{array}
$$

Ketuntasan aspek kognitif siswa dapat di tentukan dengan menggunakan ketuntasan klasikal (KK).

$$
K K=\frac{\text { Banyak siswa yang tuntas }}{\text { banyak siswa yang ikut tes }} \times 100 \%
$$

Untuk memenuhi kriteria tersebut maka skor data yang diperoleh harus dikonversi ke skala 100 dengan rumus seperti berikut ini.

$$
\text { Nilai }=\frac{\text { Skor yang diperoleh siswa }}{\text { Skor maksimum }} \times 100
$$

Pedoman penggolongan hasil belajar matematika siswa terhadap penerapan metode make a macth dinyatakan dengan Tabel 1 berikut.

Tabel 1. Pedoman penggolongan kemampuan Desain gravis vektor

\begin{tabular}{cc}
\hline Persentase Skor Total siswa & Katagori Kemampuan siswa \\
\hline $94-100$ & Sangat Baik \\
$87-93$ & Baik \\
$80-86$ & Cukup \\
$73-79$ & Kurang Baik \\
$0-72$ & Sangat Kurang Baik \\
\hline
\end{tabular}

(Sumber : KTSP SMK Negeri 1 Sukasada)

Penelitian Tindakan Kelas ini dikatakan berhasil jika terjadi peningkatan hasil belajar Desain gravis vektor siswa sesuai dengan target yang ditetapkan. Target keberhasilan penelitian ini adalah siswa mampu mencapai skor rerata yaitu minimal 80 , dan ketuntasan klasikal minimum $80 \%$.

\section{Hasil dan Pembahasan}

Data hasil belajar Corel Draw ini di ukur dari segi ketrampilan siswa atau dari aspek psikomotor. pada aspek psikomotor, siswa mengerjakan tugas proyek ketrampilan membuat cover atau logo yang dievaluasi oleh guru itu sendiri. 
pada Siklus I diperoleh data hasil belajar dengan kategori individu dan kelompok sebagai berikut: tidak ada siswa yang mendapat nilai dengan kategori sangat baik (A), 5 orang $(17,9 \%)$ memperoleh nilai dengan kategori baik (B), 5 orang $(17,9 \%)$ memperoleh nilai dengan kategori cukup (C), 14 orang (50\%) memperoleh nilai dengan kategori baik (D), dan 4 orang $(14,3 \%)$ memperoleh nilai dengan kategori sangat kurang $(E))$. Dari data hasil belajar siswa pada siklus I maka siswa yang tuntas hanya 10 orang $(35,7 \%)$ dan siswa yang tidak tuntas sebanyak 18 orang $(64,3 \%)$ Dengan ketercapainya hasil belajar siswa tersebut maka penelitian ini akan dilanjutkan ke siklus II dengan melihat kekurangan dan hambatan pada siklus I

diperoleh data hasil belajar dengan kategori individu sebagai berikut: mendapat nilai dengan kategori nilai sangat baik (A) 4 orang siswa $(14,3 \%), 19$ orang $(67,9 \%)$ memperoleh nilai dengan kategori nilai baik (B), 5 orang $(17,9 \%)$ memperoleh nilai dengan kategori nilai baik $(\mathrm{C})$. dan tidak ada siswa yang mendapat nilai kurang sangat kurang $(0 \%)$. Dari data hasil belajar pada siklus II maka siswa yang tuntas sebanyak 28 orang $(100 \%)$ atau semuanya tuntas

Persentase ketuntasan hasil belajar desain grafis vektor secara klasikal pada siklus I adalah $78,7 \%$ dan persentase ketuntasan belajar desain grafis vektor secara klasikal pada siklus II adalah $89,6 \%$. Peningkatan ketuntasan hasil belajar desain grafis vektor dari siklus I ke siklus II adalah 10,9\%. Peningkatan ini tidak terlepas dari penerapan model pembelajaran kooperatif tipe STAD secara optimal dengan perbaikan-perbaikan pembelajaran sesuai dengan kekurangan-kekurangan, hambatan dan kendala-kendala yang terjadi pada setiap siklus sebelumnya. Dari peningkatan hasil belajar desain grafis vektor merupakan bukti dari penerapan model pembelajaran kooperatif tipe STAD ini, siswa mendapat kesempatan yang luas untuk melatih keterampilan dan juga memberi waktu yang luas untuk belajar gerak baik secara individu maupun secara kelompok, suasana belajar siswa selama kegiatan pembelajaran nampak bebas, ceria, bergairah, dan kondusif. Disamping itu siswa dapat berkolaborasi dengan teman kelompoknya. Siswa belajar dan beraktivitas sendiri untuk memperoleh pengalaman, pengetahuan, pemahaman, dan tingkah laku lainnya serta mengembangkan keterampilannya yang bermakna serta mengembangkan keterampilan yang bermakna di mana siswa sudah mulai sangat aktif dan antusias selama proses pembelajaran, mampu bekerja sama dengan teman dan memahami materi pelajaran dengan sangat baik khususnya materi desain grafis vektor. Sehingga dalam hal ini, kegiatan atau gaya belajar siswa merupakan pondasi untuk mencapai hasil belajar yang lebih optimal dan keberhasilan dalam penelitian sesuai dengan teori-teori yang mendukung dalam proses pembelajaran.

Bedasarkan hal tersebutlah, bahwa dengan penerapan model pembelajaran kooperatif tipe STAD (Student Team Achievement Division) dapat meningkatkan hasil belajar desain grafis vektor siswa kelas X DKV SMK Negeri 1 Sukasada Tahun Pelajaran 2017/2018.

\section{Kesimpulan}

Berdasarkan hasil penelitian dan pembahasan dapat disimpulkan bahwa penerapan model pembelajaran STAD (student teams achievement divisions) pada mata pelajaran desain komunikasi visual dengan materi desain gravis vektor di kelas X DKV SMK N 1 Sukasada dapat meningkatkan hasil belajar siswa pada aspek kognitif dan aspek psikomotorik (hasil belajar).

\section{Daftar Pustaka}

Adiputra, I. N. (2014). Pengembangan E-Modul pada Materi "Melakukan Instalasi Sistem Operasi Jaringan Berbasis GUI dan Text" untuk Siswa Kelas X Teknik Komputer dan Jaringan SMK Negeri 3 Singaraja. Retrieved Januari 20, 2015, from Karmapati Pendidikan Teknik Informatika, Universitas Pendidikan Ganesha.

Amiroh. (2012). Membangun E-Learning dengan Learning Management System Moodle. Sidoarjo: PT Berkah Mandiri Globallindo.

Ananda, M. (2014). Pengembangan E-Learning Berbasis Schoology Pada Mata Pelajaran IPA Kelas VIII di SMP Negeri 1 Seririt. Jurusan Teknologi Pendidikan: Journal Edutech Universitas Pendidikan Ganesha. 
BSNP. 2007. Peraturan Menteri Pendidikan Nasional Republik Indonesia Nomor 41 Tentang Standar Proses Untuk Satuan Pendidikan Dasar Dan Menengah. Jakarta: Badan Standar Nasional Pendidikan.

Candiasa, I. M. (2010). Pengujian Instrumen Penelitian Disertasi ITEMAN dan BIGSTEP. Singaraja: Universitas Pendidikan Ganesha.

Depdiknas. 2006. Kurikulum Tingkat Satuan Pendidikan. Jakarta : Departemen Pendidikan Nasional

Dewi, N. K., Garminah, N. N., \& Pudjawan, K. (2013). Pengaruh Model Pembelajaran Berbasis Proyek (Project- Based Learning) Terhadap Hasil Belajar IPA Siswa Kelas IV SD N 8 Banyuning. Retrieved Januari 20, 2015, from http://download.portalgaruda.org/article. php?article=105329\&val=1342.

Dimyati dan Mudjiono. 2006. Belajar dan Pembelajaran. Jakarta: Rineka Cipta.

Firman, K. (2009). Pembelajaran Entreupreneurship Melalui Online Berdasarkan Connectivism. journal University terbuka.

Gunadharma. (2011). Pengembangan Modul Elektronik Sebagai Sumber Belajar Untuk Mata Kuliah Multimedia Design. Skripsi (tidak diterbitkan). Jurusan Teknologi Pendidikan, Fakultas IImu Pendidikan, Universitas Negeri Jakarta.

Hamalik, Oemar. 2001. Proses Belajar Mengajar. Jakarta: Bumi Aksara.

Hanum, N. S. (2013). Keefektifan E-learning Sebagai Media Pembelajaran (Studi Evaluasi Model Pembelajaran E-learning SMK Telkom Sandhy Putra Purwokerto). Jurnal Pendidikan Vokasi, Vol 3, Nomor 1, Februari 2013

Ibrahim, dkk. 2000. Pembelajaran Kooperatif. Surabaya: Universitas Negeri Surabaya.

Kanca, I Nyoman. 2010. Metode Penelitian Pengajaran Pendidikan Jasmani Dan Olahraga. Singaraja : Jurusan Pendidikan Keolahragaan Fakultas IImu Keoahragaan Universitas endidikan Ganesha Singaraja.

Mahendra, I G. (2012). Pengembangan Media Pembelajaran Berbasis Blog pada Mata Pelajaran Teknologi Informasi dan Komunikasi Kelas VII SMP Negeri 4 Sukasada. Skripsi (tidak diterbitkan) Jurusan Teknologi Pendidikan, Fakultas IImu Pendidikan, Universitas Pendidikan Ganesha.

Mardika. (2007). Konektivisme Sebagai Alternatif Teori Belajar Di Abad Digital. jurnal UNY.

Nurhasan dan S. Sukarjo. 1992. Evaluaasi Pengajaran Pendidikan Jasmani dan kesehatan. Departemen Pendidikan dan Kebudayaan. Direktorat Jenderal Pendidikan Tingkat Tinggi Proyek Pembinaan Tenaga Kependidikan.

Nurhadi, dkk. 2004. Pembelajaran Kontekstual dan Penerapannya dalam KBK. Malang: Universitas Negeri Malang.

Nurkancana dan Sunartana. 1992. Evaluasi Hasil Belajar. Surabaya : Usaha Nasional.

Putro, Binawan Rasi. 2011. Penerapan Model Pembelajaran Kooperatif STAD untuk Meningkatkan Keaktifan Belajar Geografi Siswa Kelas X9 SMAN 1 Purwosari Kompetensi Dasar Mendeskripsikan Tata Surya dan Jagad Raya. Malang: Universitas Negeri Malang.

Ratumanan, Tanwey Gerson. 2002. Belajar dan Pembelajaran. Surabaya: Unesa University Press.

Satria Adi Utama, I Komang. 2011. Implemantasi Model Pembelajaran Kooperatif Tipe Student Teams Achievement Division (STAD) Untuk Meningkatkan Aktivitas dan Hasil Belajar 
Tolak Peluru pada Siswa Kelas VIII A1 SMP N 1 Sawan Tahun Pelajaran 2010/2011. Singaraja: Jurusan Pendidikan Jasmani Kesehatan dan Rekreasi, Fakultas Olahraga dan Kesehatan, Universitas Pendidikan Ganesha.

Santyasa dan Sukadi. 2007. Model-Model Pembelajaran Inovatif. Singaraja : Undiksha.

Sudjana, Nana. 2006. Penilaian Hasil Proses Belajar Mengajar. Bandung: Remaja Rosdakarya.

Suprijono, Agus. 2009. Cooperative Learning. Yogyakarta : Pustaka Pelajar.

Slavin, Robert. E. 2010. Cooperative Learnig. Bandung: Nusa Media.

Syarifuddin, Aip. 1997. Pendidikan Jasmani dan Kesehatan 1 SLTP Kelas 1. Jakarta: PT. Grasindo.

Sugiyanto, dkk. 1998. Perkembangan dan Belajar Motorik. Jakarta: Departemen Pendidikan dan Kebudayaan. Direktorat Jenderal Pendidikan Dasar dan Menengah Bagian Proyek Peningkatan Mutu Guru Pendidikan Jasmani dan Kesehatan SD Setara D-II.

Tegeh, I. M. (2013). Pengembangan Bahan Ajar Metode Penelitian Pendidikan dengan Addie Model. Jurnal IKA, 12-26.

Utomo, Wahyu Adi. 2012. Pengaruh Model Pembelajaran Student TeamAchievement Division (STAD) Terhadap Hasil Belajar Geografi Di SMANegeri 1 Purwosari. Malang: Universitas Negeri Malang 